\title{
STRATEGI KAMPANYE PARIWISATA RELIJIUS KELENTENG KAMPIT DI DESA SENYUBUK -KAMPIT BELITUNG TIMUR
}

\author{
Agustrijanto $^{1}$, Dyah Kusumawati ${ }^{2}$ \\ Program Studi Ilmu Komunikasi, KALBIS Institute, Jakarta \\ Email: agustrijanto@kalbis.ac.id; dyah.kusumawati@kalbis.ac.id
}

\begin{abstract}
ABSTRAK
Kelenteng Kampit di Belitung Timur merupakan salah satu tujuan wisata reliji yang sangat menarik. Wisata reliji seperti ini menggubah pandangan sebagian besar masyarakat tentang fungsi rumah ibadah menjadi lebih bijak, dari sebatas dipahami sebagai wilayah pribadi hubungan vertikal manusia dengan Tuhan menjadi sebuah destinasi wisata untuk saling membuka diri dan menghormati sesama/antar pemeluk agama atau kepercayaan. Toleransi antara umat beragama berjalan baik di Beltim, terutama antara Muslim dan Budha. Penelitian mengenai strategi kampanye pemasaran pariwisata Kelenteng Kelapa Kampit di Pemkab Beltim ini menggunakan metode kualitatif dengan pendekatan deskriptif kualitatif, dan mengapresiasi teori komunikasi kampanye yang menekankan komunikasi pesan yang tertata. Paradigma penelitian ini menggunakan konstruktivisme. Penelitian ini diharapkan dapat memberikan saran, inspirasi, dan ide tentang pentingnya memasarkan destinasi wisata relijus yang gigih menyampaikan pesan-pesan perdamaian melalui wisata reliji di Kelenteng Kampit. Penelitian ini dapat dikembanglanjutkan dengan penulisan atau penelitian sejenis.
\end{abstract}

Kata kunci: komunikasi, pemasaran, pariwisata, wisata reliji,

\begin{abstract}
Kelenteng Kampit in the East Belitung is one of tourist destinations religious and it is very interesting. Tourism religious like this composes view the majority of the community about the function the temple become more wise, from limited only to inform understood as personal areas vertical relations people by The Lord has become a tourist destination for mutual open itself up and respect fellow / between adherent of the religion or faith. Tolerance between religious communities go well in Beltim, especially between Moslem and Buddhist. Research on tourism marketing campaigns strategy Kelenteng Kampit in the local government Beltim it uses the qualitative method with the approach qualitative descriptive, and appreciate communication theory a campaign that emphasizes communication a message that its operation the workshop uses. It uses in the study paradigm constructivism. This research is expected can give advice, inspiration, and ideas about the importance of convey messages of peace tour through religious in Kelenteng Kampit. This research can resumed to writing or similar research
\end{abstract}

Keyoword: Communication, marketing, tourism, religious tourism 


\section{National Conference of Creative Industry: \\ Sustainable Tourism Industry for Economic Development}

Universitas Bunda Mulia, Jakarta, 5-6 September 2018

E- ISSN No: 2622-7436

\section{PENDAHULUAN}

Wisata reliji merupakan pilihan wisata menarik dalam beberapa tahun terakhir. Hal ini diperkuat oleh berbagai faktor. Salah satunya adalah keinginan wisatawan untuk mengetahui tempat-tempat wisata berbasis agama maupun kepercayaan seperti rumah ibadah. Wisata reliji perlu dikembangkan agar tercipta saling pengertian dan sikap saling menghormati diantara seluruh komponen masyarakat terutama di antara sesama pemeluk agama dengan mengenal dan mengunjungi tempat-tempat ibadah.

Salah satu destinasi wisata reliji yang menarik adalah Kelenteng Kelapa Kampit. Disebut Kelapa Kampit karena nama Kelapa Kampit merujuk pada nama daerah sekaligus nama Kecamatan yang ada di Kabupaten Belitung Timur. Daerah Kampit sendiri merupakan salah satu wilayah yang tidak bisa dilepaskan dari sejarah pertambangan di Pulau Belitung. Kelenteng Kampit identik dengan cerita atau kisah masyarakat setempat. Kampit artinya kelapa yakni pohon kelapa tumbuh berhimpitan. Dalam bahasa Belitung, arti berhimpitan adalah dampit, kampit. Dari kata inilah kemudian timbul istilah Kelapa Kampit. Jadi, Kelenteng Kelapa Kampit dapat diartikan sebagai kelenteng yang ada di wilayah yang banyak pohon kelapa yang tumbuh berhimpitan karena subur dan jumlahnya banyak.

Kelapa yang berhimpitan tersebut konon tumbuh di sebuah Gunung Kik Karak yang memang sudah tersohor di daerah ini. Uniknya, gunung Kik Karak juga merupakan tempat tambang timah yang diduga merupakan tempat kuburan atau makam seorang kakek.

Dalam bahasa Belitung, Kik Karak artinya kakek. Tambang timah yang berada di Gunung Kik Karak Kelapa Kampit ini tergolong atau terkategori sebagai tambangdalam. Dan tambang-dalam sendiri di Indonesia merupakan satu yang terbesar setelah tambang Tikus yang memang memiliki skala dan ukuran yang lebih kecil.

Dalam sebuah catatan dinyatakan bahwa Gunung Kik Karak di Kelapa Kampit ini mampu menghasilkan 2.000 ton tambang timah per tahunnya. Dari besarnya potensi tambang di Kota Kelapa Kampit maka kemudian muncul wisata tambang yang disebut dengan Open-Pit. Jadi sebenarnya, dari letak Kelenteng Kelapa Kampit ini ternyata juga dekat dengan beberapa destinasi wisata lain seperti Pantai Sengaran, Bukit Pangkuan, dan Pasar Kelapa Kampit.

Wilayah Kelapa Kampit mempunyai tujuh kelurahan yaitu Mentawak, Buding, Cendil, Senyubuk, Pembaharuan dan Mayang. Untuk mata pencaharian masyarakat Kelapa kampit adalah penambang timah, perkerja perkebunan sawit dan nelayan. (disarikan dari www.belitungisland.com/new/_destination)

Keunikan Kelenteng Kelapa Kampit dapat dideskripsikan sebagai berikut

Tabel 1 Kelenteng Kampit

\begin{tabular}{|c|c|c|}
\hline No & Aspek & Penjelasan \\
\hline 1 & Fisik & $\begin{array}{l}\text { Kelenteng Kampit memiliki kekhasan bentuk bergaya Tiongkok klasik. Bahan baku } \\
\text { yang digunakan untuk pembuatan Kelenteng Kampit didatangkan dari Tiongkok } \\
\text { sehingga nuansa Tiongkok-nya begitu kental. } \\
\text { Kelenteng Kampit ini terkenal sebagai Kelenteng paling unik di wilayah Belitung } \\
\text { Timur karena letakknya yang berada di pusat keramaian pasar namun menambah } \\
\text { keindahan lingkungan sekitar. } \\
\text { Kelenteng ini juga menjadi kebanggaan warga dan semua warga apapun agama dan } \\
\text { sukunya secara bersama-sama menjaga Kelenteng Kampit dengan baik. }\end{array}$ \\
\hline
\end{tabular}




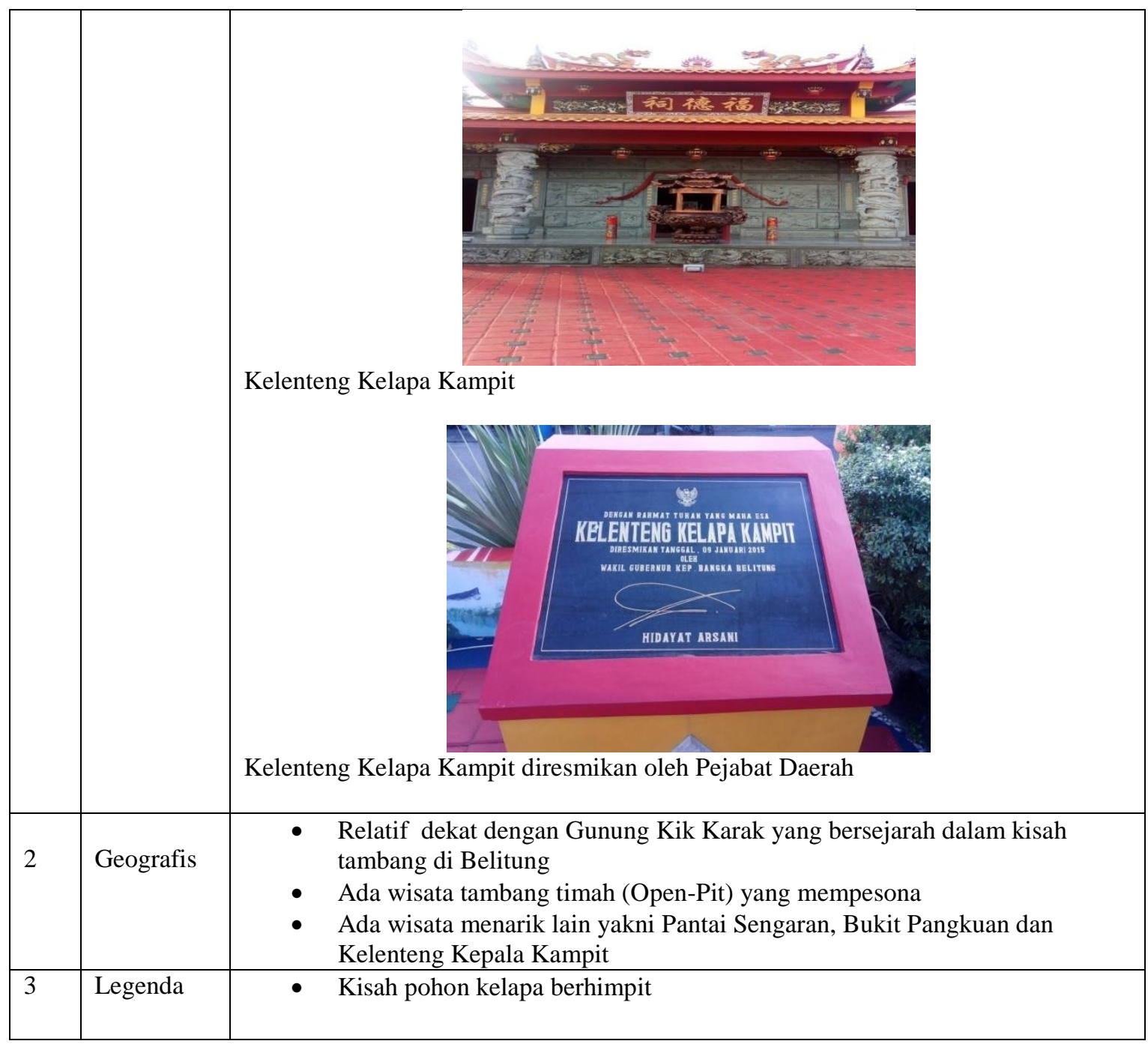

Dihubungkan dengan data dari Dinas Pariwisata Kabupaten Belitung Timur yang menyebutkan ada 12 dua belas wisata unggulan di wilayah Belitung Timur yaitu

1. Obyek wisata open pit

2. Pantai Burong Mandi

3. Kelenteng Dewi Kwan Im

4. Pantai Nyiur Melambai

5. Pantai Punai

6. Pulau Buku Limau
7. Replika SD Laskar Pelangi

8. Situs Makam Raja Balok

9. Museum kata

10. Kampung Ahok

11. Dermaga Kirana dan Rumah Keong

12. Obyek wisata Unik Ngenjungak

Maka dapat dicermati bahwa wisata reliji menempati posisi yang penting yang direpresentasikan oleh kelenteng Dewi Kwan Im di peringkat ketiga, dan Situs Makam Raja Balok di peringkat ke delapan.

Wisata reliji perlu dikembangkan dengan lebih kreatif karena di dalam aktivitas pariwisata reliji tertera banyak keuntungan yang sifatnya fisik dan non fisik. Yang disebut keuntungan fisik adalah obyek wisata reliji ini merupakan obyek yang secara fisik memang sangat menarik dan menggugah hasrat orang untuk mengunjunginya. Biasanya keindahan suatu tempat ibadah didukung oleh faktor lain seperti alam 


\section{National Conference of Creative Industry: \\ Sustainable Tourism Industry for Economic Development}

Universitas Bunda Mulia, Jakarta, 5-6 September 2018

E- ISSN No: 2622-7436

sekeliling yang indah, sarana transportasi yang terjangkau, hingga ketersediaan fasilitas yang memadai.

Di sisi lain, keuntungan non fisik yang akan diterima oleh masyarakat di sekitar tempat ibadah wisata reliji adalah terbukanya jaringan informasi, hubungan baik, dan kemitraan yang akan sangat membantu kemajuan wilayah tersebut seperti misalnya dari aspek ekonomi, social dan budaya. Oleh karena itu perlu dikembangkan kegiatan komunikasi yang dapat memasarkan potensi pariwisata suatu tempat ibadah. Dalam hal ini komunikasi pemasaran yang sifatnya terpadu dan saling bersinergi penting dipertimbangkan untuk diterapkan mengingat di dalam komunikasi pemasaran wisata reliji turut diperhitungkan aspek brand, brand destination, dan brand.

Brand adalah merek, logo, sebagai sebuah identitas produk, jasa, atau obyek yang akan dipasarkan. Sementara brand destination merupakan brand yang menjadi merek, logo, tagline, sebagai identitas wilayah pelancongan. Branding adalah kata aktif yang yang menunjukkan dan memasarkan brand. Destinasi adalah ranah pelancongan, wilayah wisata yang akan dituju.

Penelitian ini mengedepankan komunikasi pemasaran untuk mempromosikan wisata reliji Kelenteng Kampit dengan nilai-nilai positifnya yakni perdamaian, persaudaraan, cinta kasih dan kepedulian diantara sesama umat beragama, khususnya Budha dan Muslim di Kampit. Dengan demikian wisara reliji dapat menjadi pilihan wisata yang positif yakni edukasi dalam aktivitas wisatawan yang dilakukan wisatawan domestic maupun luar negeri.

Kegiatan komunikasi pemasaran terpadu untuk mempromosikan wisata reliji Kelenteng Kampit merupakan salah satu kunci untuk mensukseskan tujuan pemasaran wisata reliji itu sendiri, dalam hal ini Kelenteng Kampit sebagai tujuan wisata reliji dikomunikasikan sebagai obyek dan daya tarik wisata yang efektif agar tercapai tujuan pemasaran pariwisata yaitu kepuasan wisatawan.

Jika kepuasan wisatawan terhadap destinasi Kelenteng Kampit tercapai maka komunikasi pemasaran yang dilaksanakan dapat dikatakan sukses. Komunikasi pemasaran memegang peranan yang sangat penting bagi pemasar. Tanpa komunikasi pemasaran, konsumen maupun masyarakat secara keseluruhan tidak akan mengetahui keberadaan produk, jasa dan obyek yang dipasarkan. pemasaran. Penelitian ini merumuskan masalah bagaimana strategi komunikasi pemasaran wisata reliji pada Kelenteng Kampit Di Desa Senyubuk Belitung Timur, dan bertujuan untuk mengetahui bagaimana strategi komunikasi pemasaran wisata reliji pada Kelenteng Kampit Di Desa Senyubuk Belitung Timur dilaksanakan untuk mempromosikan Kelenteng Kampit sebagai destinasi wisata reliji

\section{Strategi}

Strategi berasal dari kata Yunani yaitu stratos (tentara) dan agein (memimpin). Jadi secara sederhana strategi dapat diartikan sebagai cara-cara memimpin seperti layaknya dalam dunia militer. Ada juga kata strategos yang berarti pemimpin tentara di tingkat atas. Secara teknis, strategi dapat disebut sebagai konsep militer yang diartikan sebagai seni berperang par ajenderal (the art of general), atau suatu rancangan terbaik untuk memenangkan peperangan. Dalam strategi ada prinsip yang harus dicamkan yakni tidak ada sesuatu yang berarti dari segalanya kecuali mengetahui apa yang akan dikerjakan musuh sebelum musuh mengerjakannya (Cangara, 2013: 61). 
Strategi menghasilkan gagasan dan konsepsi yang dikembangkan oleh para praktisi yang konsisten dengan keilmuannya. Maka tidak heran kalau makna strategi tidak hanya milik dunia militer tetapi semua cabang keilmuan, apakah itu ekonomi, matematika, dan komunikasi.

Tahapan strategi dibentuk berdasarkan tahapan-tahapan analisis yang:

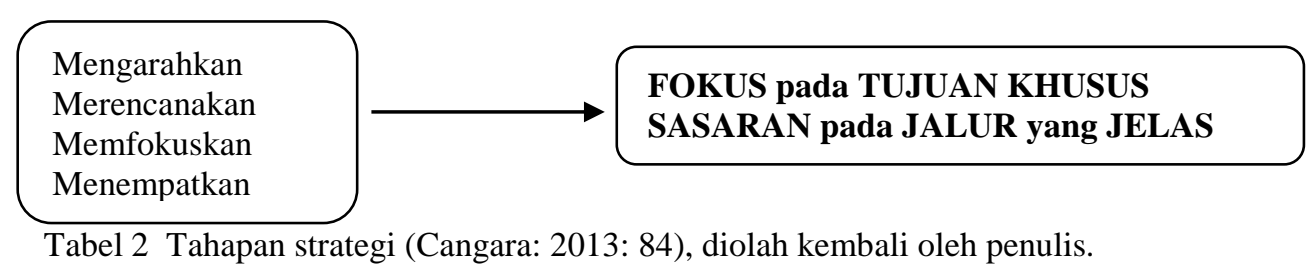

Strategi diperlukan dalam merencanakan pesan komunikasi karena pesan komunikasi dicpitakan tidak hanya selesai di titik sampai (received) tapi juga harus dipasrtikan jika pesan komunikasi tersebut diterima (accepted) dan direspon sesuai kehendak si pengirim pesan. Oleh karena itu unsur-unsur dalam strategi perencanaan pesan memiliki tujuan menentukan sasaran komunikasi, cara berkomunikasi dan kredibilitas komunikator. Dalam hal ini Pemerintah Daerah Belitung Timur sebagai komunikator yaitu pihak yang menggagas ide dan program dalam rangka memasarkan Kelenteng Kampit sebagai destinasi wisata dengan keunggulannya yaitu keindahan lokasi Kampit dan pesan-pesan perdamaian yang dapat digemakan kepada para pengunjung local maupun interlokal.

Strategi juga menempatkan latar belakang wisatawan sebagai audiens. Penempatan audiens sasar ini biasanya didasarkan pada identifikasi audiens, latar belakang audiens, dan perasaan audiens. Ketiga hal ini membentuk cara menyusun strategi komunikasi pemasaran yang sarat pesan-pesan yang jitu bagi penerima pesan dan pesan-pesan yang terorganisasi, termasuk melakukan pendekatan budaya dan pemilihan media promosi yang tepat.

Strategi dalam pemahaman sederhana adalah arahan, atau perencanaan yang sifatnya teknis yang siap dilaksanakan. Strategi memang belum dilaksanakan tapi arti belum dilaksanakan di sini bukan berarti kelalaian, keabaian, atau kemalasan. Strategi hanya dapat dilakukan dengan perhitungan waktu yang tepat karena strategi berisi kisikisi, rundown, pola detil, penjelasan runut, dan petunjuk pelaksanaan suatu rencana yang wajib diformat sedemikian teliti. Jadi tidak dapat disebut strategi jika masih ditemukan kesalahan di sana sini. Materi yang tidak siap, atau evaluasi yang kurang meyakinkan. 
Mengingat urgenitas strategi yang tinggi maka sudah seharusnya jika pembuatan dan penyusunan strategi dilakukan dengan matang agar tidak sia-sia. Oleh karena itu, strategi harus disusun dengan menggunakan rumus:

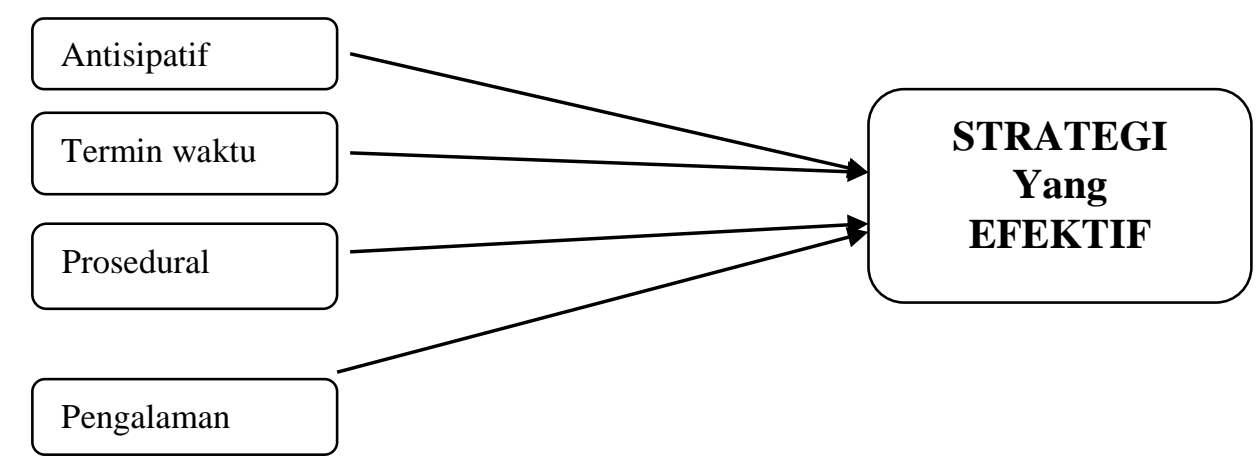

Tabel 3. Aspek-Aspek Penyusunan Strategi (disarikan oleh Penulis dari Perencanaan Strategi - Cangara)

\section{Kampanye}

Segala upaya dan rencana yang ditujukan untuk mengubah prilaku audiens sasar sesuai dengan target yang digagas dapat disebut sebagai aktivitas kampanye. Kampanye tidak hanya bicara soal sebuah program menjadi popular atau tidak, sebuah ajang menjadi memiliki nilai jual atau tidak, melainkan lebih dari itu yaitu: bagaimana mengomunikasikan pesan-pesan kampanye menjadi rujukan prilaku yang diharapkan dapat dipahami, dan dilakukan dari target sasar. Kampanye memang berisi pesan-pesan komunikasi (kampanye itu sendiri) sehingga kampanye harus memiliki arah, tujuan, dan market.

Beragam kepentingan program yang bersatu atau disatukan dengan membentuk sinergi yang tujuannya mencapai target bersama dapat disebut sebagai Kampanye. Kampanye melibatkan berbagai disiplin keilmuan, ia tidak dapat berdiri sendiri melainkan dirancang sebagai sebuah kesatuan yang memiliki sendi, gagasan dan alur kerja yang jelas.

Kampanye komunikasi memiliki tujuan-tujuan tertentu seperti: mensosialisasikan suatu program yang telah digagas (dapat bersifat sosial, pendidikan, politik, atau semua hal yang berkaitan dengan misi khusus suatu organisasi). Untuk mencapai tujuan kampanye maka kampanye harus dilakukan melalui beberapa tahapan, yaitu

a. Analisis situasi, yakni kemampuan mencermati, menangkap masalah dalam kehidupan publik, seperti fenomena hubungan antar umat beragama yang bervariasi. Di Kelenteng Kampit hubungan harmonis antar umat beragama khususnya Budha dan Muslim sudah berlangsung baik selama ratusan tahun.

b. Penetapan tujuan, yaitu langkah yang dilakukan untuk menjawab permasalahan. Dari sini maka akan dapat disasar, tujuan apa yang akan dicapai, dan pihak mana yang menjadi tujuan strategi komunikasi pemasaran dalam memasarkan Kelenteng Kampit.

c. Penetapan khalayak yaitu mempertegas bahwa semua pihak atau masyarakat yang memiliki kepentingan dengan destinasi wisata Kelenteng Kampit dapat disebut sebagai khalayak sasar. Pemerintah Daerah Belitung Timur sebagai 


\section{National Conference of Creative Industry: \\ Sustainable Tourism Industry for Economic Development}

Universitas Bunda Mulia, Jakarta, 5-6 September 2018

E- ISSN No: 2622-7436

pemilik otoritas wiayah dapat melakukan berbagai hal yang dirasa perlu untuk memajukan wisata reliji di daerahnya.

d. Pemilihan media, yaitu tindakan yang bersifat efisiensi terhadap media-media dala menetapkan strategi komunikasi pemasaran tentang Kelenteng Kampit kepada audiens dengan jitu.

e. Penentuan anggaran yaitu komponen yang turut menentukan keberhasilan suatu kampanye karena anggaran berkaitan erat dengan seluruh aktivitas kegiatan kampanye maka harus dirancang dengan cermat.

f. Pengukuran hasil atau evaluasi, yaitu keberanian untuk menilai apakah suatu program kampanye telah dilakukan dengan baik, mencapai sasaran, atau sebaliknya (Prita Kemal Gani, Kampanye Humas, LSPR-edu, 2013, dan diolah kembali oleh penulis).

\section{Pariwisata}

Pariwisata adalah konsep yang multidimensi. Pariwisata memiliki banyak arti.

Definisi pariwisata memang tidak dapat persis sama di antara para ahli, hal yang memang jamak terjadi dalam dunia akademis, sebagaimana juga bisa di temui pada berbagai disiplin ilmu lain. Meskipun demikian, beberapa persamaan tentang persyaratan sebuah pariwisata adalah

1. Traveler, yaitu orang yang melakukan perjalanan antar dua atau lebih lokasi

2. Visitor, yaitu orang yang melakukan perjalanan ke daerah yang bukan merupakan tempat tinggalnya, kurang dari 12 bulan, dan tujuan perjalanannya bukanlah untuk terlibat dalam kegiatan untuk mencari nafkah, pendapatan, atau penghidup di tempat tujuan.

3. Tourist, yaitu bagian dari visitor yang menghabiskan waktu paling tidak satu malam (24 jam) di daerah yang dikunjungi (WTO, 1995).

Semua definisi yang dikemukakan selalu mengandung beberapa unsur pokok, yaitu:

1. Adanya unsur travel (perjalanan), yaitu pergerakan manusia dari satu tempat ke tempat lain.

2. Adanya unsur 'tinggal sementara' ditempat yang bukan merupakan tempat tinggal yang biasanya, dan

3. Tujuan dari pergerakan manusia tersebut bukan untuk mencari penghidupan/pekerjaan di tempat yang di tuju (richardson and fluker 2004: 5)

Selanjutnya, Mathieson (1982) mengatakan bahwa pariwisata mencakup tiga elemen utama, yaitu:

1. a dynamic element, yaitu travel ke suatu destinasi wisata.

2. a static element, yaitu singgah di daerah tujuan dan

3. a consequental element, atau akibat dari dua hal di atas (khususnya terhadap masyarakat lokal), yang meliputi dampak ekonomi, sosial dan fisik dari adanya kontak dengan wisatwan.

Lebih jelasnya secara teknis, dapat dilihat pengertian konsep pariwisata seperti tabel di bawah ini:

Tabel 4. Konsep Pariwisata

\begin{tabular}{|l|l|l|}
\hline NO & Konsep & \multicolumn{1}{c|}{ Keterangan } \\
\hline 1. & Visitor $(V)$ & $\begin{array}{l}\text { Pengunjung, orang yang berkunjung, pihak yang mengunjungi, melakukan } \\
\text { perjalanan dengan berbagai tujuanuk leisure, bisnis, perjalanan } \\
\text { religius/agama, kesehatan, dan sebagainya }\end{array}$ \\
\hline
\end{tabular}




\begin{tabular}{|c|c|c|}
\hline 2. & $\begin{array}{l}\text { Tourist }(T): \\
\text { Stay-over lovernight }\end{array}$ & $\begin{array}{l}\text { Visitor yang bermalam, tinggal lebih dari satu malam, bisa karena alasan } \\
\text { komersial maupun non komersial }\end{array}$ \\
\hline 3. & $\begin{array}{l}\text { Same-day visitor } \\
(S D) \text { : } \text { excursionist, } \\
\text { Day-visitor }\end{array}$ & 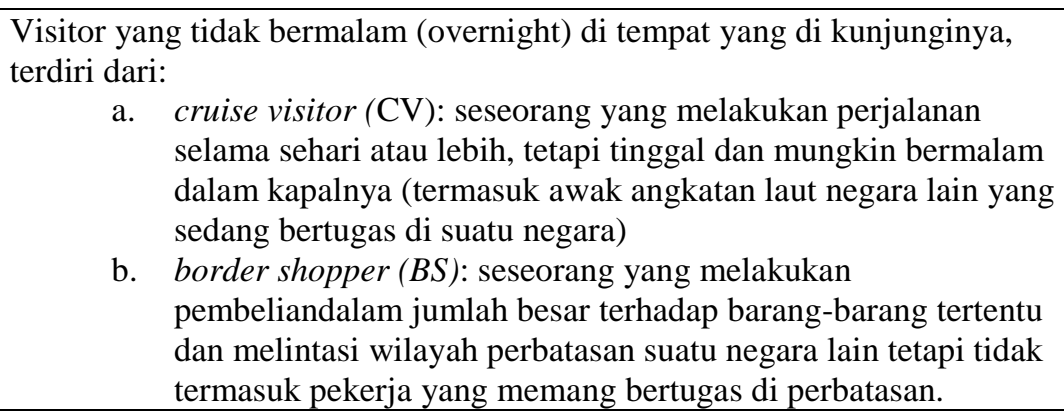 \\
\hline 4. & Traveller & $\begin{array}{l}\text { Visitor dan: } \\
\text { a. direct transit traveler }(D T) \text {, yaitu saat di airport, dan antara dua } \\
\text { pelabuhan berdekatan. } \\
\text { b. Commuters, yaitu perjalanan rutin ke tempat kerja, studi, atau } \\
\text { belanja, dan sebagainya. } \\
\text { c. Other noncommuting travel (ONT), yaitu berupa perjalanan } \\
\text { khusu, awak transport atau awak perusahaan travel komersial, } \\
\text { buruh migran (termasuk pekerja tidak tetap), diplomat (ke dan } \\
\text { dari tempat tugas). }\end{array}$ \\
\hline 5 & $\begin{array}{l}\text { Passanger atau } \\
\text { penumpang }(P A X, \\
\text { Revenue })\end{array}$ & $\begin{array}{l}\text { Traveller kecuali dan tidak termasuk crew (awak) transport, non-revenue } \\
\text { (low revenue) traveler seperti bayi, perjalanan Cuma-Cuma (gratis) atau } \\
\text { dengan potongan harga } 25 \% \text { atau lebih. }\end{array}$ \\
\hline 6 & $\begin{array}{l}\text { Tourism } \\
\text { (pariwisata) }\end{array}$ & $\begin{array}{l}\text { Aktivitas dari visitor, orang yang melakukan perjalanan ke dan tinggal di } \\
\text { tempat di di luar tempat tinggalnya (residen) sehari-hari untuk periode } \\
\text { tidak lebih dari } 12 \text { bulan untuk beragam kegiatan leisure, bisnis, agama, } \\
\text { dan alasan pribadi lainnya tetapi tidak mendapat upah/gaji dari } \\
\text { perjalanannya tersebut. }\end{array}$ \\
\hline 7 & Tourism industry & $\begin{array}{l}\text { Bisnis atau perusahaan penyediaan layanan dan barang kepada visitor, } \\
\text { termasuk: } \\
\text { a. Hospitality (hotel dan restoran, dll.) } \\
\text { b. Transportasi } \\
\text { c. Tur operator dan biro perjalanan, atraksi wisata, dll } \\
\text { Usaha-usaha ekonomi lain yang mendukung kebutuhan visitor (beberapa } \\
\text { darinya termasuk penyedia layanan dan barang yang signifikan bagi visitor } \\
\text { maupun non-visitor) }\end{array}$ \\
\hline 8 & $\begin{array}{l}\text { The travel and } \\
\text { tourism industry } \\
\text { (TTI) }\end{array}$ & $\begin{array}{l}\text { Tourism industry dan usaha/bisnis penyediaan jasa/layanan dan barang } \\
\text { kepada other non-communiting traveler }\end{array}$ \\
\hline
\end{tabular}

Sumber: Pengantar Ilmu Pariwissata ( I Gde Pitana: 53)

Aspek-aspek pariwisata dalam tabel di atas telah mengklasifikasi beberapa pengertian mendasar tentang pariwisata dan hal-hal penting lainnya yang bias amelingkupi dunia kepariwisataan.

\section{Komunikasi Pemasaran}

Komunikasi pada dasarnya adalah penyampaian dan penerimaan pesan-pesan komunikasi. Untuk mencapai komunikasi yang efektif maka diperlukan tindakan terorganisasi yang tujuannya memersuasif pesan sehingga komunikasi menjadi lebih lancar, cair, dan aman. Salah satunya adalah menggunakan model AIDA - (attention, ineret-desire-action). AIDA sebenarnya rumus klasik dalam komunikasi pemasaran yang relative masih relevan untuk digunakan kareana di dalam AIDA dikemukakan 


\section{National Conference of Creative Industry: \\ Sustainable Tourism Industry for Economic Development}

Universitas Bunda Mulia, Jakarta, 5-6 September 2018

E- ISSN No: 2622-7436

masing-masing peran yang untuk membuat sebuah program komunikasi menjadi berhasil.

Secara harfiah, komunikasi pemasaran berarti memadupadankan antara kekuatan komunikasi dan pemasaran. Jika komunikasi diartikan sebagai pertukaran pesan dan respon yang diharapkan terjadi sesuai maksud dan tujuan komunikasi itu sendiri maka pemasaran dapat diidentikkan sebagai tindakan aktif yang bertujuan mempromosikan atau menjual sesuatu sehingga komunikasi pemasaran dapat diartikan sebagai komunikasi yang menyampaikan pesan-pesan pemasaran kepada target audiens. Tujuan pemasaran menjadi target utama yaitu dengan cara membentuk, membangun dan menyampaikan pesan-pesan komunikasi.

Pemasaran sudah terlanjur dimaknai bahwa focus utamanya adalah menjual produk kepada konsumen. Dari kata menjual saja sudah dapat ditangkap makna bahwa pemasaran tidak jauh-jauh dari kegiatan penjualan produk, dan profit financial. Namun seiring waktu dan perkembangan ilmu marketing maka dalam dunia pemasaran, banyak hal yang dapat dijual dan banyak hal yang dapat dikategorikan sebagai keuntungan seperti misalnya hubungan baik, jaringan antara para pihak yang prospektif, promosi atau iklan yang emosional positif, dan testimoni-testimoni yang menguntungkan dan memberikan citra yang baik.

\section{Komunikasi Pariwisata}

Pariwisata dapat menjadi sebuah konsep manakala didefinisikan sebagai produk bisnis modern. Sebagai bagian dari bisnis maka pariwisata akan dikaitkan dengan sarana dan prasarana yang menunjang. Pemahaman sebagian pihak yang menyatakan bahwa pariwisata identik dengan keindahan alam harus ditinjau ulang lagi karena perkembangan pariwisata telah melampaui bayangan orang kebanyakkan.

Hal ini disebabkan oleh munculnya kesadaran bahwa pariwisata merupakan sebuah industri juga sehingga memiliki komponen-komponen penting seperti tujuan pelancongan yang diinginkan, transportasi yang mendukung terciptanya, strategi pemasaran destinasi wisata, dan kelembagaan pariwisata.

Komunikasi memegang peranan sangat penting bagi keberhasilan menyampaikan pesan-pesan wisata yang melekat pada obyek wisata. Hal ini disebabkan karena komunikasi bersifat kompleks artinya komunikasi pariwisata dapat dikatakan sebagai komunikasi yang berperan menyiapkan konten pesan-pesan wisata yang harus disampaikan kepada masyarakat, wisatawan, atau audiens target tentang apa yang seharusnya mereka tahu tentang media-media pemasaran, destinasi, aksebilitas, dan SDM serta kelembagaan pariwisata. (Bungin.2015: 94)

Dari pemaparan di atas maka dapat dicermati bahwa komunikasi pariwisata mengkaji keseluruhan konteks pemasaran yang dialokasikan bagi perkembangan dunia pariwisata. Secara klasik, rumus $4 \mathrm{P}$ (price, product, place, promotion) merupakan pendekatan pemasaran yang paling mungkin dilakukan untuk membedah komunikasi pemasaran pariwisata karena di dalamnya terdapat pertimbangan-pertimbangan yang harus diperhatikan dalam mengembangkan potensi-potensi pariwisata.

Dengan memerhatikan konsep 4P maka pariwisata dapat diidentifikasikan sebagai aktivitas masyarakat yang memfasilitasi pergerakan wisatawan dan implikasi atau akibat-akibat pergerakan wisatawan serta aktivitas masyarakat yang memfasilitasinya terhadap kehidupan masyarakat secara luas" sehingga pariwisata merupakan suatu usaha yang memiliki potensi: 
National Conference of Creative Industry: Sustainable Tourism Industry for Economic Development

Universitas Bunda Mulia, Jakarta, 5-6 September 2018

E- ISSN No: 2622-7436

1. Mengembangkan Jasa Wisata.

2. Membangun organisasi-organisasi perjalanan.

3. Menyusun kebijakan Pembangunan Pariwisata..

Tabel 4. Komponen dan elemen penting pariwisata

\begin{tabular}{|c|c|c|c|}
\hline \multicolumn{4}{|c|}{ KOMPONEN PARIWISATA } \\
\hline Pemasaran & Aksesibiltas & Destinasi & $\begin{array}{c}\text { Sumber daya dan } \\
\text { kelembagaan pariwisata }\end{array}$ \\
\hline $\begin{array}{l}\text { Jasa } \\
\text { informasi }\end{array}$ & Transportasi & $\begin{array}{l}\text { Daya tarik wisata; view, budaya, } \\
\text { tradisi, religi, dan lain-lain }\end{array}$ & Konsultan pariwisata \\
\hline $\begin{array}{l}\text { Alat } \\
\text { informasi }\end{array}$ & $\begin{array}{l}\text { Udara, laut, } \\
\text { darat; kereta } \\
\text { api, bus, } \\
\text { pribadi }\end{array}$ & $\begin{array}{l}\text { Kawasan pariwisata; eko-wisata, } \\
\text { wisata sport,wisata belanja, } \\
\text { wisata religi, wisata kuliner, } \\
\text { wisata kesenian, wisata pantai }\end{array}$ & $\begin{array}{l}\text { Tersedianya pakar dan } \\
\text { ilmuan pariwisata }\end{array}$ \\
\hline $\begin{array}{l}\text { Metode } \\
\text { informasi }\end{array}$ & Travel agen & $\begin{array}{l}\text { Hospitality (kebersihan, } \\
\text { keramahan, kenyamanan, } \\
\text { keamanan) }\end{array}$ & $\begin{array}{l}\text { Ketersediaan SDM } \\
\text { pariwisata terampil; hotel, } \\
\text { guiding, kulinari, seni, } \\
\text { industri, dan sebagainya }\end{array}$ \\
\hline $\begin{array}{l}\text { Agen-agen } \\
\text { informasi } \\
\text { pariwisata }\end{array}$ & $\begin{array}{l}\text { Kemudahan } \\
\text { mendapatkan } \\
\text { trasportasi }\end{array}$ & $\begin{array}{l}\text { Hotel, motel, guese house, } \\
\text { rumah rakyat }\end{array}$ & $\begin{array}{l}\text { Regulasi dan kebijakan } \\
\text { publik di dalam negeri } \\
\text { yang berdampak positif } \\
\text { terhadap pariwisata }\end{array}$ \\
\hline $\begin{array}{l}\text { Komitmen } \\
\text { pemerintah } \\
\text { terhadap } \\
\text { pariwisata }\end{array}$ & Map & Atraksi; hiburan dan rekreasi & $\begin{array}{l}\text { Keterbutuhan masyarakat } \\
\text { terhadap wisatawan }\end{array}$ \\
\hline & $\begin{array}{l}\text { Fasilitasi dan } \\
\text { kebersihan di } \\
\text { bandara, } \\
\text { pelabuhan dan } \\
\text { terminal }\end{array}$ & Venue MICE & $\begin{array}{l}\text { Tersedianya sumber- } \\
\text { sumber informasi } \\
\text { pariwisata }\end{array}$ \\
\hline & $\begin{array}{l}\text { Fasilitasi di } \\
\text { tempat-tempat } \\
\text { perhentian } \\
\text { jalan darat }\end{array}$ & Wisata air; air terjun, air laut & $\begin{array}{l}\text { Dukungan lembaga adat } \\
\text { dan tokoh masyarakat } \\
\text { terhadap pariwisata }\end{array}$ \\
\hline & & Wisata Spa-Relaksasi & Pramuwisata \\
\hline & & Jasa perjalanan wisata lokal & $\begin{array}{l}\text { Regulasi dan kebijakan } \\
\text { politik internasional yang } \\
\text { berdampak terhadap } \\
\text { pariwisata }\end{array}$ \\
\hline & & kulinari & \\
\hline & & $\begin{array}{l}\text { Souvenir, oleh-oleh dan industri } \\
\text { kreatif }\end{array}$ & \\
\hline & & $\begin{array}{l}\text { Persewaan alat selam, pancing, } \\
\text { sepeda, olahraga, panjat tebing, } \\
\text { gunung, dan sebagainya }\end{array}$ & \\
\hline
\end{tabular}

Sumber: Komunikasi Pariwisata (Bungin:87)

Dalam pandangan penulis, komponen pariwisata memuat segala hal yang menjadi perhatian, kajian, dan obyek kepariwisataan yang kerap kali menjadi perhatian bagi setiap aktivitas pariwisata. 


\section{National Conference of Creative Industry: \\ Sustainable Tourism Industry for Economic Development}

Universitas Bunda Mulia, Jakarta, 5-6 September 2018

E- ISSN No: 2622-7436

\section{Komunikasi Pariwisata dan Pemasaran Modern}

Kottler (2006) mempopulerkan konsep price (harga), product (produk), place (pasar), promotion (promosi). Konsep ini menempatkan manusia sebagai subjek utamanya. Sementara Seaton dan Benelt (Vellas \& Becherel, 2008), mengidentifikasikan lima ciri penting pemasaran pariwisata:

a. Memiliki falsafah yang berorientasipada pelanggan.

b. Menggunakan prosedur dan konsep analisis.

c. Memanfaatkan teknik pengumpulan data.

d. Memiliki struktur organisasi.

e. Berada pada wilayah keputusan strategik dan fungsi.

Baik pandangan Kottler dan Seaton dan Benelt menekankan pada orientasi pemasaran yang mengutamakan segmentasi dimana segmentasi ini membagi tingkat kebutuhan yang diperlukan dalam mengembangkan bisnis kepariwisataan.

\section{Strategi Komunikasi Pemasaran Pariwisata: Destinasi}

Destinasi merupakan ragam produk pariwisata, seperti wahana, tempat tinggal yang berdekatan, taman bertema (theme parks), hotel country club, dan perkampungan liburan. Oleh sebab itu destinasi merupakan hal penting karena dalam pengembangan strategi komunikasi pemasaran, setiap badan / institusi harus memperimbangkan tujuan dari mitra usah dan pemilik serta betas-batas pengendalian.

Visi Pariwisata Kementrian Kebudayaan dan Pariwisata Indonesia, adalah "wujudnya bangsa Indonesia yang mampu memperkuat jati diri dan watak bangsa serta meningkatnya lesejahteraan masyarakat". Yang kemudian dimaknai sebagai;

1. melestarikan nilai, keragaman dan kekayaan budaya dalam usaha memperkukuh jati diri dan karekter bangsa;

2. mengembangkan industri pariwisata berdaya saing, destinasi yang berkelanjutan dan melaksanakan pemasaran yang bertanggung jawab (responsible marketing);

3. mengembangkan sumber daya kebudayaan dan pariwisata;

4. menciptakan tata pemerintahan yang resposif., tulus, dan terpercaya (Rencana Strategis Kementrian Kebudayaan dan Kepariwisataan 2010-2014, 2010).

Wisata reliji dengan dasar pendekatan komunikasi pemasaran sebenarnya melekatkan obyek destinasi wisata yaitu rumah ibadah sebagai obyek yang memiliki daya tarik bagi pengembangan pariwisata di wilayah yang dituju.

Candi, kelenteng, masjid, pura, vihara merupakan contoh-contoh tempat ibadah yang layak diperhitungkan sebagai destinasi baru bagi pengembangan pariwisata. Wisata reliji ini tidak hanya membawa pesan-pesan keagamaan melainkan juga pesanpesan komunikasi perdamaian, wisatawan tidak hanya menikmati keindahan fisik bangunan tetapi turut merasakan impresi kejiwaan dari kehadiran relung-relung relijius yang dipromosikan dalam obyek wisata rumah ibadah.

Destinasi atau tempat tujuan melancong adalah wilayah tempat obyek wisata berada dan menjadi daya tarik bagi wisatawan. Akibatnya adalah tujuan wisata ini akan dipandang sebagai sebuah komponen yang lebih luas (tidak hanya obyek rumah ibadahnya saja) melainkan juga tanah sekitar, masyarakat sekitar, hingga pemerintah 


\section{National Conference of Creative Industry: \\ Sustainable Tourism Industry for Economic Development}

Universitas Bunda Mulia, Jakarta, 5-6 September 2018

E- ISSN No: 2622-7436

daerah setempat. Pertimbangan ini muncul karena memasarkan sebuah destinasi memiliki keunikkan tersendiri. Oleh karena itu pengembangan komunikasi pemasaran wisata reliji harus menyinergikan faktor-faktor yang melekat pada rumah ibadah sebagai obyek wisata yang dimaksud.

\section{Metode Penelitian}

Penelitian ini menggunakan metode penelitian kualitatif dengan jenis penelitian studi kasus yang menghasilkan data deskriptif yang berupa kata-kata tertulis atau lisan dari orang-orang dan perilaku yang dapat diamati. Sugiyono mendefinisikan metode penelitian kualitatif adalah metode penelitian yang digunakan untuk meneliti pada kondisi obyek yang alamiah, dimana peneliti adalah sebagai instrumen kunci, teknik pengumpulan data dilakukan secara trianggulasi (gabungan), analisis data bersifat induktif, dan hasil penelitian kualitatif lebih menekankan makna dari pada generalisasi. (Sugiyono, 2007:1). Dengan digunakan metode kualitatif, maka data yang didapat akan lebih lengkap, lebih mendalam, kredibel, dan bermakna sehingga tujuan penelitian dapat dicapai. Adapun objek penelitian dalam penelitian ini adalah Kelenteng Kampit sebagai destinasi wisata di Belitung TImur yang sarat dengan keindahan dan pesan-pesan perdamaian antara Muslim dan Budha khususnya, serta sesama umat beragama pada umumnya.

Peneliti meneliti dengan cara studi literatur yakni menganalisis komunikasi pemasaran pariwisata Pemerintah Daerah Belitung Timur dalam memasarkan destinasi wisata Kelenteng Kampit dimana Kelenteng Kampit merupakan obyek penelitian ini. Peneliti juga melakukan kunjungan langsung ke destinasi wisata dan melakukan wawancara mendalam dengan para pihak yang terlibat dalam pengembangan potensi wisata kelenteng Kampit. Data primer dalam penelitian ini adalah data yang peneliti mengambilnya langsung dari sumber berupa kunjungan ke lokasi penelitian, termasuk mewawancarai informan yang berkompeten. Dalam hal ini peneliti mewawancarai:

Tabel 5. Narasumber

\begin{tabular}{|c|l|l|}
\hline 1 & $\begin{array}{l}\text { Bapak Helly Tjandra } \\
\text { Kepala Dinas Pariwisata Pemerintah Kabupaten Belitung Timur }\end{array}$ & Key Informan \\
\hline 2 & $\begin{array}{l}\text { Bapak Adiguna } \\
\text { Staf Divisi Pamong Budaya Dinas Pariwisata Kabupaten Belitung Timur }\end{array}$ & $\begin{array}{l}\text { Informan } \\
\text { Pbu Icin }\end{array}$ \\
\hline 4 & $\begin{array}{l}\text { Bapak Widiyanto } \\
\text { Kepala Bidang Destinasi Wisata Pemerintah Kabupaten Belitung Timur }\end{array}$ & Informan \\
\hline 5. & $\begin{array}{l}\text { Bapak Peranciscus Aryanto, SE } \\
\text { Kepala Seksi Kelembagaan Kepariwisataan Dinas Kebudayaan dan Pariwisata } \\
\text { Kabupaten Belitung Timur }\end{array}$ & Informan \\
\hline
\end{tabular}

Adapun data sekunder yang berupa dokumen-dokumen atau arsip-arsip, bukubuku literatur,jurnal ilmiah, artikel dan website yang berkaitan dengan fokus peneliti.

\section{Hasil Penelitian dan Pembahasan}

Strategi kampanye pariwisata pariwisata relijius Kelenteng Kampit di Desa Senyubuk Kampit Belitung Timur adalah strategi yang dikembangkan oleh pemerintah daerah Belitung Timur (Pemkab Beltim) yang melibatkan sejumlah instrumen terkait dengan menggunakan beberapa tindakan promotif dan inisiatif. Pemkab Beltim menempatkan jenis pariwisata Vihara Kelapa Kampit sebagai pariwisata berklasifikasi spiritual, dan memiliki nuansa semangat keagamaan. Di sisi lain, jenis pariwisata reliji 


\section{National Conference of Creative Industry: \\ Sustainable Tourism Industry for Economic Development}

Universitas Bunda Mulia, Jakarta, 5-6 September 2018

E- ISSN No: 2622-7436

seperti Kelenteng Kampit merupakan pariwisata yang mengedepankan nilai sejarah, dan budaya. Aspek relijius, budaya dan keindahan alam telah menjadi pendekatan dalam menstrategikan wisata relijius dalam hal ini Kelenteng Kampit.

Menurut Bapak Widiyanto selaku Kepala Bidang Destinasi Wisata Pemerintah Kabupaten Belitung Timur, tempat ibadah memang memiliki pesona tersendiri.

“... wisata relijius itu obyek wisatanya adalah rumah ibadah yang tentu menampilkan nilai-nilai reliji tertentu yang merujuk pada agama sehingga wajar jika tempat ibadah itu mempunyai daya tarik. Secara fisik, Kelenteng Kampit memiliki keindahan bergaya Tiongkok..."

Aspek pendukung Kelenteng Kampit adalah lokasinya yang berada di pusat keramaian yakni pasar, atau area publik di pinggir jalan, dan mempertemukan titik-titik jalan di daerah Kampit. Akibatnya bangunan Kelenteng Kampit menjadi bangunan yang mudah dikenali dan diingat (ikonik). Bahkan dalam beberapa diskusi atau pandangan umum masyarakat, Kelenteng Kampit telah menjadi ikon Kampit bagi masyarakat luas. Di sisi lain, ternyata Kelenteng Kampit juga dikenal dengan nama Kelenteng Fu De Ce terutama bagi kalangan Tionghoa. Keunikan Kelenteng Kampit telah terkenal dan menjadi kisah yang selalu diceritakan oleh wisatawan yang pernah berkunjung ke Belitung Timur. Menurut Ibu Icin - salah seorang pengurus harian di Kelenteng Kampit,

“... kalau orang sudah berada di Kelenteng Kampit Fu De Ce, rasanya seperti sedang berada di Tiongkok. Ornamen-ornamennya memang asli didatangkan dari Cina, sangat kental budaya Cina-nya. Padahal ini di Belitung Timur Indonesia. Kelenteng Kampit ini dikunjungi banyak pengunjung. Ada yang datang untuk beribadah, atau sekedar berfoto saja. Mungkin karena ini kelenteng paling mewah di wilayah Kampit. Turis ada yang dari luar negeri. Ada yang datang dari Jerman Australia, Eropa, India, Taiwan, dan RRC. Dari Indonesia banyak lagi. Bagus lah kalau begini .. Kelenteng Kampit bisa makin maju dan terkenal. Semua pengunjung ya kami perlakukan dengan baik, mereka kan tamu kami ya.. mau yang Kristen, Budha, Hindu, Konghucu, Islam ... ya kita sama ya .. umat Tuhan..."

Pandangan Ibu Icin pengurus harian Kelenteng Kampit yang penuh kedamain ini juga menjadi daya tarik tersendiri bagi wilayah Kampit. Hampir tidak pernah ada konflik atau gesekan karena perbedaan kepercayaan. Sepanjang peneliti bersosialisasi dengan masyarakat sekitar, masyarakat selalu menegaskan bahwa kehidupan beragama di Belitung Timur dapat dikatakan berjalan dengan baik.

Kelenteng Kampit sering disebut sebagai kelenteng terindah kedua setelah Kelenteng Dewi Kwan Im. Kepopuleran kelenteng Dewi Kwan Im disebabkan oleh jalur transportasi menuju lokasi yang lebih mudah dicapai oleh pengunjung. Hal ini membuat banyak pengunjung merasakan kemudahan akomodasi serta informasi tentang keberadaan Kelenteng Dewi Kwan Im yang lebih sering terekspos frekwensinya.

Kenyataan yang menunjukkan jika Kelenteng Dewi Kwan Inn merupakan kelenteng utama, dinyatakan dalam pernyataan Bapak Helly Tjandra selaku Kepala Dinas Pariwisata Pemerintah Kabupaten Belitung Timur, 


\section{National Conference of Creative Industry: \\ Sustainable Tourism Industry for Economic Development}

Universitas Bunda Mulia, Jakarta, 5-6 September 2018

E- ISSN No: 2622-7436

“... vihara Dewi Kwan Inn merupakan salah satu destinasi wisata reliji yang mendapat apresiasi dari Dinas Pariwisata Pemkab Beltim. Pemkab Beltim dengan antusias memanfaatkan media sosial untuk mempromosikannya karena kami menyadari bahwa obyek wisata reliji merupakan obyek wisata potensial yang selalu berkembang. Daya tarik wisata reiji selain keindahan tempat ibadahnya adalah adanya keyakinan sebagian pengunjungnya bahwa di tempat seperti itu (Kwan Inn) akan bertabur keajaiban dan keberkahan, tentu saja hal ini berlaku bagi yang percaya saja.."

Dari pemaparan tersebut dapat dicermati bahwa dalam aktivitas wisata reliji selain menikmati keindahan fisik juga ada hal-hal yang bersifat psikis yang mendorong wisatawan datang. Lebih lanjut, Bapak Helly Tjandra mengatakan,

“. obyek wisata di Belitung Timur ini akan selalu berkembang, termasuk wisata reliji yang dekat dengan wisata alam. Pengembangannya bisa bersinergi karena alam geografis Belitung Timur memang indah. Oleh karena itu, Pemkab Beltim menggunakan cara icon diary atau sistem icon diary yakni mengingormasikan secara khusus obyek wisata reliji tersebut ke dalam informasi-informasi kepariwisataaan formal Beltim sehingga obyek wisata reliji seperti Vihara Dewi Kwan Inn dan yang lainnya (Kelenteng Kampit) dapat lebih dikenal. Kami mencermati bahwa wisata reliji ternyata bukan untuk satu agama tertentu saja melainkan untuk wisatawan yang memang memiliki ketertarikan mengunjunginya, baik karena alasan keindahan dan keunikan bangunannya, alam sekitarnya, maupun untuk pengetahuan."

Pemkab Beltim telah menginformasikan tentang wisata reliji kelenteng Kampit secara icon diary dalam informasi-informasi pariwisata Beltim, yaitu suatu teknik yang menempatkan obyek wisata reliji sebagai ikon di wilayah yang dimaksud. Kelenteng Kampit adalah ikon wilayah Kampit. Cara ini diinformasikan dalam bentuk promo below the line (brosur, banner, pamflet, poster, spanduk dan sejenisnya) serta cara above the line (seperti radio, TV, dan media sosial), di samping melaksanakan even-even yang mengangkat pariwisata Beltim (ajang Bujang Dayang).

Kelenteng Kampit berada di pusat keramaian (dibandingkan dengan Vihara Dewi Kwan Inn yang berada di dekat laut) sehingga bangunan Kelenteng Kampit sangat ikonik. Besar kemungkinan orang yang melewati atau mengunjungi Kampit pasti akan melewati atau melihat bangunan kelenteng Kampit ini.

Letak geografis menuju lokasi Kelenteng Kampit telah menjadi perhatian lama PemkabBeltim khususnya Dinas Pariwisata. Menurut bapak Bapak Peranciscus Aryanto, SE selaku Kepala Seksi Kelembagaan Kepariwisataan Dinas Kebudayaan dan Pariwisata Kabupaten Belitung Timur:

“... pada dasarnya Pemkab Beltim memerhatikan perkembangan wisata reliji seperti Kelenteng Kampit atau Fu De Ce. Kelenteng Kampit merupakan Kelenteng yang sudah direnovasi atas kerjasama Pemkab dan masyarakat. Tepatnya sekitar tahun 2017, Kelenteng Kampit diresmikan lebih megah. Membangun kawasan wisata reliji Kelenteng Kampit memerlukan banyak perhatian. Di Beltim ada kelenteng induk Dewi Kwan Inn dan kelenteng pendukung Kelenteng Kampit. Pembangunan fisik menuju Kelenteng Kampit masih harus ditingkatkan terutama jalan karena banyak pengunjung yang merasa nyaman mengunjungi kawasan Kampit menggunakan mobil kecil atau mobil penumpang biasa, bukan bis besar. Perjalanan menuju Kelenteng Kampit dari 
Bandara terasa lebih jauh daripada ke kelenteng Kwan Inn. Namun ini menjadi tantangan antara Pemkab Beltim, Dinas Pekerjaan Umum, dan masyarakat."

Menyimak pemaparan bapak Peranciscus di atas maka dapat dicermati bahwa pembangunan fisik dapat memengaruhi keberhasilan pemasaran pawisata Kelenteng Kampit. Wisatawan memiliki rasa naluriah untuk memenuhi keingintahuannya tentang kelenteng Kampit. Dalam hal ini, bapak Adiguna - Staf Divisi Pamong Budaya Dinas Pariwisata Kabupaten Belitung Timur menyatakan,

“... wisata reliji (seperti kelenteng Kampit) mengundang keingintahuan wisatawan untuk mengunjunginya. Wisata reliji ke Kelenteng Kampit menawarkan sesnasi yang unik. Wisata reliji Kelenteng Kampit menjual nilai harmonis, perdamaian dan persaudaraan sesama umat manusia. Jadi wisata reliji tidak hanya menjual fisik keindahan bangunan. Belitung Timur mewariskan toleransi dan perdamaian antar suku dan agama, tidak pernah terjadi konflik karena suku atau agama di sini.",

Mencermati pemaparan di atas maka penulis berpandangan bahwa straegi kampanye pariwisata Kelenteng Kampit adalah menyampaikan segenap informasi tentang Kelenteng Kampit dengan melakukan kerjasama antara Pemkab Beltim sebagai institusi formal dan masyarakat. Walau secara area promosi masih di tingkat regional namun mengampanyekan icon diary Beltim merupakan salah satu cara efektif dalam mengomunikasikan kampanye pariwisata Beltim. Beltim yang selama ini kerap disebut sebagai saingan Pulau Dewata Bali untuk wisata pantainya dapat lebih mempromosikan diri melalui keunggulan dan kedamaian kehidupan umat beragama. Wisata reliji Beltim dapat lebih gencar mempromosikan nilai-nilai perdamaian dalam hubungan antar umat beragama.

Tabel 6. Bagan Strategi Kampanye Pariwisata Kelenteng Kampit (hasil olahan Penulis)

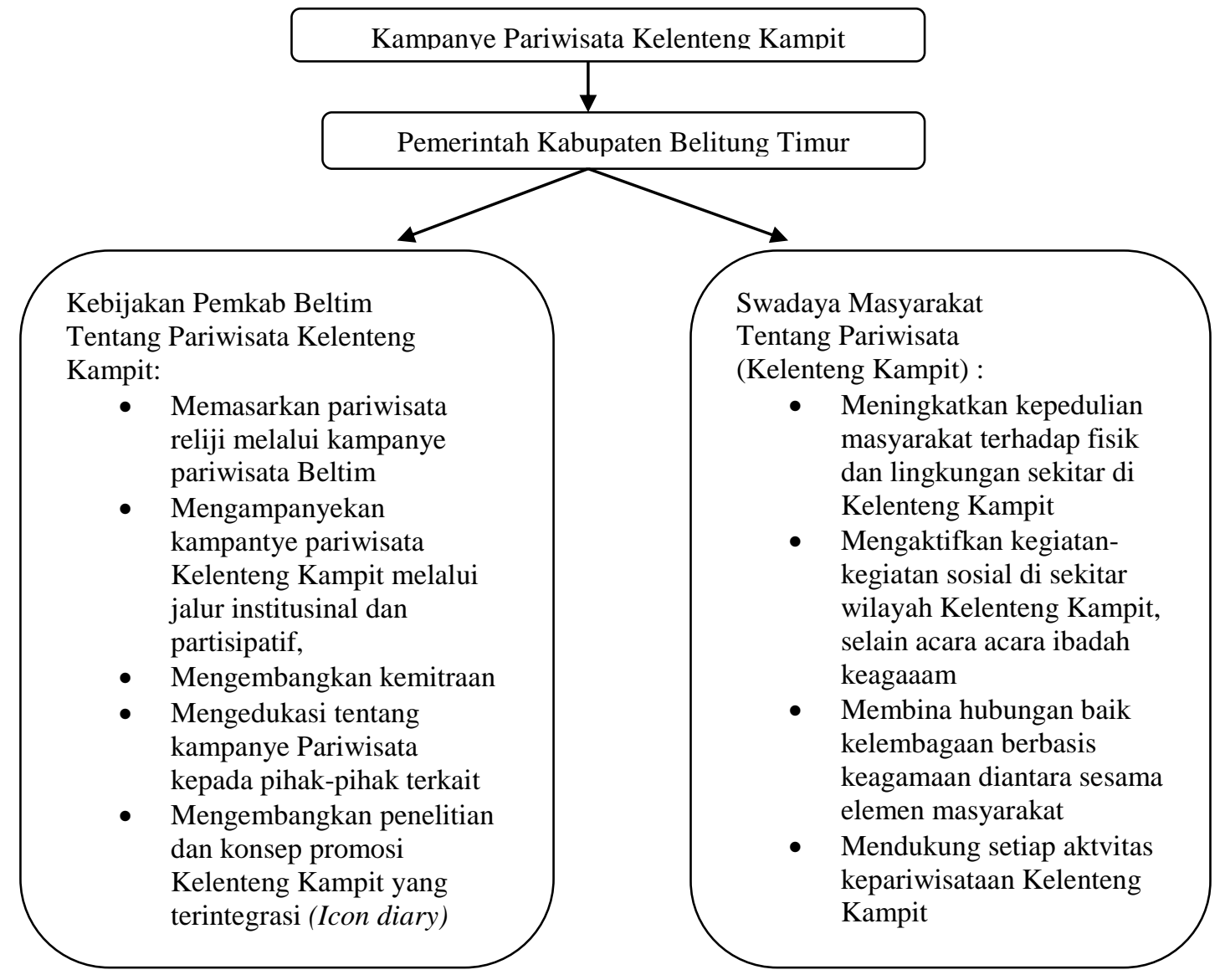




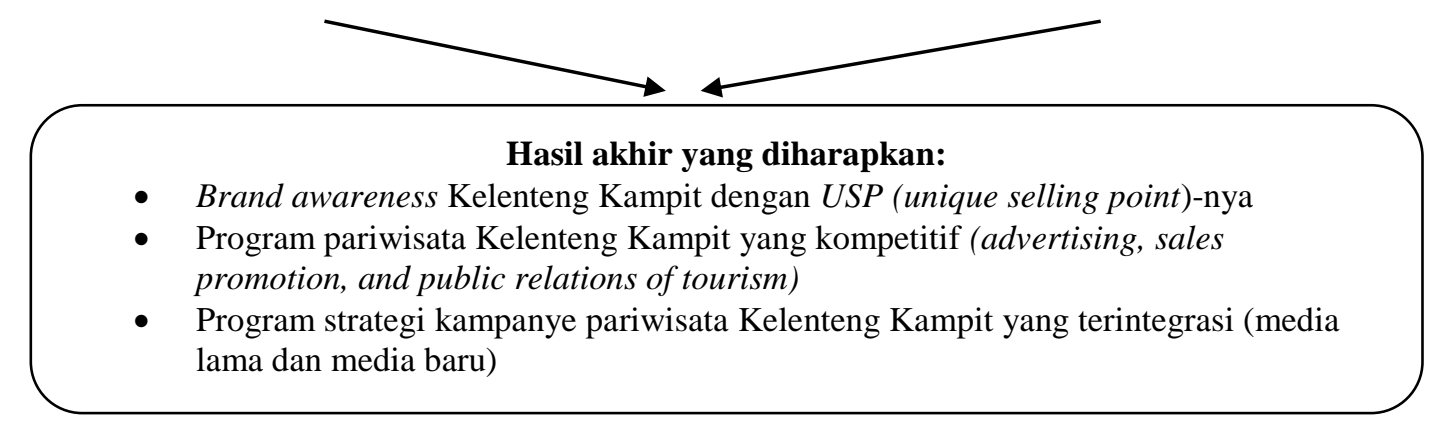

\section{Penutup}

Strategi kampanye pariwisiata relijus Kelenteng Kampit telah mengedepankan koordinasi antara institusi formal yakni Pemerintah Kabupaten Belitung Timur dengan partisipasi masyarakat. Mengingat begitu besarnya tantangan Pemkab Beltim dalam mengembangkan wisata reliji Kelenteng Kampit maka pada aspek pengenalan dan penguatan branding Kelenteng Kampit sebagai icon diary Kampit dapat menjadi kajian yang benar-benar diperhatikan. Penggunaan icon diary yakni menginformasikan suatu obyek pariwisata yang terus menerus dan teratur pada beberapa media promosi merupakan cara sederhana untuk menguatkan branding Kelenteng Kampit sebagai sebuah wiayah wisata reliji di Beltim yang diperhitungkan, dan menjadi mitra destinasi dengan kelenteng utama yakni Dewi Kwan Inn.

Mengampanyekan pariwisata relijius Kelenteng Kampit yang ditangani oleh Pemkab Beltim merupakan suatu hal yang menarik karena sebagai insstitusi / pemerintah Daerah, pihak Pemkab Beltim harus dapat menangkan peluang dan perkembangan wisata reliji . Dari pertimbangan-perrtimbangan pemasaran yakni harga, lokasi, produk, dan promosi maka ada baiknya Pemkab Beltim mengembangkan konsep promosi yang berkelanjutan.

Pemkab Beltim telah melakukan hal yang terbaik bagi pengembangan wisata relijius Kelenteng Kampit di wilayahnya. Yang perlu diamati juga adalah bahwa persaingan wisata reliji di berbagai daerah di Indonesia akan semakin ketat. Hal ini akan mengasah kecerdasan ide dalam menggagas bentuk pariwisata relijius yang lebih dinamis seperti mensinergikan dengan keindahan alam, pesan-pesan perdamaian dan konsisi sosial budaya masyarakat yang mendukung.

Penelitian penulis ini bersifat terbuka sehingga akan lebih elok jika ada penelitian lanjutan mengenai kampanye pariwisata relijius terkini dengan mengembangkan konsep dan gagasan yang lebih segar agar menjadi lebih baik lagi. 


\section{National Conference of Creative Industry: \\ Sustainable Tourism Industry for Economic Development}

Universitas Bunda Mulia, Jakarta, 5-6 September 2018

E- ISSN No: 2622-7436

\section{DAFTAR PUSTAKA}

Aat, Susie, Feliza. (2017). Model Komunikasi pariwisata yang Berbasiskan Kearifan Lokal:

Studi Deskriptif Kualitatif Di Wilayah Lembang Kabupaten Bandung Barat Program Studi Hubungan Masyarakat Universitas Padjadjaran Bandung, Jurnal The Message. Volume 9 Nomor 2 Tahun 2017 Universitas Semarang

Bungin, B. (2015). Komunikasi Pariwisata. Jakarta: Prenadamedia

Cangara, H. (2013), Perencanaan dan Strategi Komunikasi, Jakarta: PT Rajagrafindo.

Dinas Pariwisata Belitung TImur, Data Obyek Wisata Unggulan, 2017

FX A, Heru. (2016). Pengembanggan Pola Komunikasi Pariwisata Berbasis Kearifan Lokal. Studi Kasus Dinas Pariwisata Kabupaten Pangandaran Sebagai Upaya Meningkatkan Kunjungan Wisatawan. Jurnal Ilmu Komunikasi. Volume 7 Nomor 1 Edisi Maret 2016

Kriyantono. (2021). Riset Komunikasi. Jakarta: Kencana

Lalongkoe, M.Ramses dan Edison. (2014), Komunikasi Terapeutik, Jakarta: Graha Ilmu.

Litlejhon and Karen. (2016). Teori Komunikasi diterjemahkan oleh Tri Wibowo, Jakarta,

Kencana

Leonita-Agustrijanto (2010). Modul Perkuliahan Perencanaan Strategis Periklanan,, Jakarta: Paramadina.

Moleong, L.J. (2007). Metodologi Penelitian Kualitatif, Bandung: PT Remaja Rosdakarya.

Pitana, dan Diarta (2009). Pengantar Ilmu Pariwisata, Yogyakarta, Penerbit Andi

Rakmat, J \& Ibrahim,I.S. (2016). Metode Penelitian Komunikasi Dilengkapi Contoh Analisis

Statistik dan Penafsirannya. Edisi Revisi. Bandung: Simbiosa Rekatama Media

Salim, A. (2006). Teori dan paradigm Penelitian Sosial. Yogyakarta: Tiara Wacana Sugiyono (2007). Memahami Penelitian Kualitatif. Bandung: CV Alfabeta.

Suyono, F. (2016). Strategi Komunikasi Pemasaran Dinas Pariwisata, Kebudayaan,

Pemuda dan Olahraga dalam Upaya Mengembangkan pariwisata diKabupaten Situbondo. Jurnal Universitas Muhamadiyah Jember: Mediakom No 1 Tahun 2017.

Venus,A. (2010). Manajemen Kampanye. Bandung: Simbiosa Rekatama Media 